Research article

\title{
Early inflammatory markers in elicitation of allergic contact dermatitis
}

\author{
Andrea Martín1, Norberto Gallino², Julio Gagliardi², Susana Ortiz ${ }^{3}$, \\ Alejandro Ruiz Lascano ${ }^{4}$, Ana Diller ${ }^{5}$, María Cristina Daraio ${ }^{2}$, Adrián Kahn², \\ Ana Lía Mariani ${ }^{6}$ and Horacio Marcelo Serra $\dagger^{*} 1$
}

Address: ${ }^{1}$ Dpto. Bioquímica Clínica, Facultad de Ciencias Químicas - Universidad Nacional de Córdoba, Córdoba, Argentina, ${ }^{2}$ Servicio de Alergia e Inmunología, Hospital Privado. Córdoba, Argentina, ${ }^{3}$ Patología, Facultad de Ciencias Químicas - Universidad Nacional de Córdoba, Córdoba, Argentina, ${ }^{4}$ Servicio de Dermatología, Hospital Privado, Córdoba, Argentina, 5 Patología, Hospital Privado, Córdoba, Argentina and 6 Universidad Nacional de Misiones (UNaM), Argentina

E-mail: Andrea Martín - amartin@bioclin.fcq.unc.edu.ar; Norberto Gallino - alergia@ hospitalprivado.com.ar; Julio Gagliardi - alergia@ hospitalprivado.com.ar; Susana Ortiz - susy07@powernet.com;

Alejandro Lascano - dermatologia@ hospitalprivado.com.ar; Ana Diller - patologia@hospitalprivado.com.ar;

María Daraio - alergia@hospitalprivado.com.ar; Adrián Kahn - alergia@hospitalprivado.com.ar; Ana Mariani - almariani@arnet.com.ar;

Horacio Serra* - hserra@bioclin.fcq.unc.edu.ar

${ }^{*}$ Corresponding author †Equal contributors

Published: 7 August 2002

BMC Dermatology 2002, 2:9

This article is available from: http://www.biomedcentral.com/I47I-5945/2/9

(C) 2002 Martín et al; licensee BioMed Central Ltd. This article is published in Open Access: verbatim copying and redistribution of this article are permitted in all media for any non-commercial purpose, provided this notice is preserved along with the article's original URL.

Keywords: Allergic contact dermatitis, CS-1 fibronectin, CCL17
Received: 9 May 2002

Accepted: 7 August 2002

\begin{abstract}
Background: Allergic Contact Dermatitis (ACD) is regarded as a T-cell-mediated delayed-type hypersensitivity reaction. We studied the kinetics of the expression of CS-I fibronectin, thymus and activation-regulated chemokine (CCLI7/ TARC) and different chemokine receptors (CR) in skin biopsies from individuals suffering from back problems, with the antigen responsible of their contact dermatitis and an irrelevant antigen.
\end{abstract}

Methods: Samples were taken at 2, 10, and 48 hours for histological and immunohistochemical studies using monoclonal antibodies against human CS-I fibronectin, CCLI7, CD3, CD68, CD49d, CXCR3, CCR5, and CCR3.

Results: At positive antigen stimulated sites there was an early expression of CS-I fibronectin (2 hours), followed by CCLI7 and a later accumulation of alplha4/betal+ (CD49d), CD3+, CD68+, CXCR3 + and CCR5 + mononuclear cells. At 48 hours, approximately $59 \%$ of infiltrating cells were CXCR3+, $42 \%$ CCR5+, and only $14 \%$ CCR3+.

Conclusions: These results showed for the first time a very early expression of CS-I fibronectin which preceded production of CCLI7 in blood endothelial cells (BCEs) from patients' skin with ACD. The role of these molecules in recruitment of monocytes and effector T cells in ACD is discussed.

\section{Background}

Allergic contact dermatitis (ACD) is one of the most common inflammatory diseases of the skin regarded as a prototype of T-cell-mediated delayed-type hypersensitivity reaction with a sensitization phase, generally asymptomatic, an effector and resolution phases [1]. Its development increases with age, the distribution in the population is rather heterogeneous, its incidence and 
prevalence in children and adolescents is largely unknown, and its socioeconomic impact as an acquired, jobrelated disease is enormous $[2,3]$. The clinical spectrum and diagnostic tools of the contact hypersensitivity reaction has been reviewed elsewhere [4-6].

Haptens and epidermal cytokines activate Langerhans cells (LCs) triggering a complex process that results in migration of these cells to the draining lymph nodes [7]. Moreover, mature dendritic cells (DCs) have a particular kinetics of cytokine production that impact on priming of different effector and memory $\mathrm{T}$ cells [8]. In addition recent results have demonstrated that CD209-ICAM-2 interaction regulates chemokine-induced transmigration of DCs across both resting and activated endothelium [9], and that in vitro treatment of human transforming growth factor-beta1-treated monocyte-derived DCs with haptens can induce the phenotypic and functional changes similar to LCs in the initiation phase of ACD [10].

The pathophysiological events in ACD are clearly mediated by skin-homing T cells and for the most common inducer, Nickel (Ni), the molecular requirements for its recognition by DCs and $\mathrm{T}$ lymphocytes have indicated that uptake and processing mechanisms may not play a major role [11] and specific combinations of TCR alphaand beta-chains are required excluding a superantigenlike activation $[12,13]$. However, during the last two years a large body of data has provided support for the idea that ACD may not be a traditional type IV hypersensitivity. In mice, neutrophil infiltration of hapten challenge sites is required for elicitation of contact dermatitis and suggest that neutrophils mediate recruitment of the specific CD8+ $\mathrm{T}$ cells that subsequently produce cytokines mediating the hypersensitivity response $[14,15]$. Moreover, the co-expression of Th1 and Th2 cytokines during contact allergy is an important feature of murine contact allergy in responsive mice [16].

The effector mechanisms are heterogeneous because keratinocytes can not only be target as thought in the pass by CD4+ T cells [17] but also by multiple hapten-specific cytotoxic $\mathrm{T}$ lymphocytes responses. Tc1 and Tc2 displayed a significant cytotoxic activity against resting sensitizermodified keratinocytes which is preferentially mediated by perforin [18]. Recent studies have shown that Natural Killer T cells, B-1 cells and TCR $\gamma \delta$ T cells are involved in contact sensitivity [19].

In spite of the surprising findings of preferential in vitro synthesis of Th2 cytokines by peripheral blood mononuclear cells and $\mathrm{T}$ cell clones derived from individuals with $\operatorname{ACD}[20,21]$, the majority of experiences to date reveals that contact allergens stimulate the selective development of type 1 immune responses and that keratinocyte apop- tosis caused in different ways by skin-infiltrating $\mathrm{T}$ cells is a key event in the pathogenesis of this disease [22-24].

Treatments at present time are avoidance of contact with the sensitizer or the use of different drugs such as corticosteroids, cyclosporine and vitamin D3 [25], but the increase knowledge of the immunopathogenic mechanisms involved in ACD will help in the near future to develop new therapeutic strategies to target key molecules in this inflammatory process and thereby diminish the aberrant immune response in a more effective way and with less undesirable effects.

Some studies have shown that elevated expression of TARC (CCL17), CTACK (CCL27), eotaxin (CCL11), eotaxin-2 (CCL24), and MCP-4 (CCL13) play an important role in the recruitment of CCR4+ or CCR3+ inflammatory cells into human skin in atopic inflammation [26-29]. More recently Goebeler et al have elegantly provided evidences that migrating effector cells during elicitation of ACD encounter multiple chemoattractant signals in a complex spatial and temporal pattern [30].

CS-1 fibronectin, the connecting segment-1 motif present in an alternatively spliced variant of fibronectin is an important ligand for $\alpha 4 \beta 1$ integrin [31]. This molecule has already been shown to be selectively expressed in synovial endothelium from biopsies with rheumatoid arthritis but not in normal synovium [32]. Since there is not too much information about the role of blood endothelial cells (BECs) in early inflammation and subsequent accumulation of mononuclear cells to challenge sites during ACD we decided to studied the kinetics of the expression of CS1 fibronectin in comparison with TARC/CCL17 which was until our results the earliest inflammatory marker of inflamed BECs.

\section{Methods}

\section{Human subjects}

Subjects already diagnosed with ACD $(n=10)$ were recruited from the Allergy Clinic at the Hospital Privado (Córdoba, Argentina). Inclusion criteria were as follows: 1) age between 23-65 years, 2) history of ACD, 3) absence of any other illness, and 4) positive skin patch tests at 48 hours to any antigen from the Patchkit Standard (FDA Allergenic Ltda., Rio de Janeiro, Brazil). Patients gave informed consent and the protocol was approved by the Institutional Ethics Committee. Patients were not taking oral or topical medication during at least one month before the beginning of this study.

\section{Study design and processing specimens}

Non irritating concentrations of antigens were applied under 8-mm Finn chambers on Scanpor tape in the scapular area at $5 \mathrm{~cm}$ of the spine. Using this method three cham- 
bers containing the antigen responsible for the ACD (positive antigen) and one chamber with a non relevant antigen (negative control) were used in each patient. Macroscopic responses were measured at 2, 10, 48 hours by evaluating skin erythema, papule and vesicle using the following arbitrary units $(-=$ absent,$+=$ mild,$++=$ moder ate, $+++=$ intense).

A $3 \mathrm{~mm}$ disposable biopsy punch was used to take a biopsy form the center of each reaction at 2, 10, 48 hours after using $1 \%$ lidocaine for local anesthesia. The control site (negative antigen) was biopsied only at 48 hours. In this way, each patient served as his/her own control. Tissue biopsies were immediately fixed in $4 \%$ buffered formalin, $\mathrm{pH} 7,4$ and then were embedded in low-temperature paraffin wax. Serial sections $(6 \mu \mathrm{m})$ were cut from biopsies, mounted on $0.1 \%$ poly-L-lysine-coated slides, dried overnight at $37^{\circ} \mathrm{C}$ and stored until use.

\section{Histology}

One skin section from each biopsy was processed for histologic conventional study and stained with hematoxilin/ eosin. The mononuclear cell infiltration in the dermis was studied and classified as follow: scattered (+/-), mild $(+)$, moderate $(++)$ and intense $(+++)$.

\section{Immunohistochemistry}

Skin sections $(6 \mu \mathrm{m})$ were dewaxed, rehydrated and then boiled in Vector antigen unmasking solution (catalog \#H-
3300, Vector Lab., Inc., Burlingame, CA, USA) in an 850$\mathrm{W}$ microwave oven for 10 minutes. Then the sections were washed in Phosphate Buffer Saline (PBS - pH 7,6) during 20 minutes and the endogenous peroxidase activity in skin was blocked with 3\% hydrogen peroxide (Sigma Chemical Co., Saint Louis, Missouri, USA) in PBS during 5 minutes and, subsequently washed thoroughly with PBS. To block unspecific sites tissue samples were incubated with 3\% bovine serum albumin (Sigma Chemical Co., Saint Louis, Missouri, USA) in PBS during 20 minutes, incubated overnight at $4{ }^{\circ} \mathrm{C}$ with anti-CD3 at 1:50, antiCD68 at 1:100 (Dako, Glostrup, Denmark) or anti- $\alpha 4 \beta 1$ 1:6 (CD49d clone P4C2, CYTEL CORPORATION, San Diego, CA, USA) or incubated for two hours at room temperature with one of the following mAbs: mouse anti-human CXCR3 (clone 1C6), anti-CCR5 (clone 2D7), anti-CCR3 (clone 7B11), anti-CCL17/TARC (clone 2D8) at $10 \mu \mathrm{g}$ per $\mathrm{ml}$, or anti-CS1 fibronectin at 1:60 (clone 90.45, CYTEL CORPORATION, San Diego, CA, USA). All mAbs against chemokine and chemokine receptors were kindly provided by LeukoSite Inc., Cambridge, MA. Isotype-matched immunoglobulins were used as negative controls. After washing with PBS, the slides were incubated with the labelled streptavidin-biotin (LSAB) method according to manufacturer's instruction (DAKO, Carpentería, CA, USA). All incubations were performed at room temperature in a humid chamber, and the reaction cascade was visualized by incubation with 3-amino-9-ethylcarbazole (AEC) as substrate (DAKO, Carpentería, CA, USA). The

Table I: Clinical and histological characteristics of ACD patients.

\begin{tabular}{|c|c|c|c|c|c|c|c|c|c|c|c|c|}
\hline \multirow[t]{3}{*}{ Patients } & \multirow[t]{3}{*}{ Sex } & \multirow[t]{3}{*}{ Age } & \multicolumn{2}{|c|}{ Skin Patch Test Reactivity } & \multicolumn{4}{|c|}{ Macroscopic response* } & \multicolumn{4}{|c|}{ Histologic grade ${ }^{* *}$} \\
\hline & & & \multirow[t]{2}{*}{ Positive Antigen } & \multirow[t]{2}{*}{ Negative Antigen } & \multicolumn{3}{|c|}{ Positive Antigen } & \multirow{2}{*}{$\begin{array}{c}\text { Negative Antigen } \\
48 \mathrm{~h}\end{array}$} & \multicolumn{3}{|c|}{ Positive Antigen } & \multirow{2}{*}{$\begin{array}{c}\text { Negative Antigen } \\
48 \mathrm{~h}\end{array}$} \\
\hline & & & & & $2 \mathrm{~h}$ & $10 \mathrm{~h}$ & $48 \mathrm{~h}$ & & $2 \mathrm{~h}$ & $10 \mathrm{~h}$ & $48 \mathrm{~h}$ & \\
\hline MO & $\mathrm{F}$ & 58 & Neomicine & Antraquinone & - & - & +++ & - & $+/-$ & $+/-$ & +++ & $+/-$ \\
\hline$M R$ & $M$ & 65 & Thimerosal & Antraquinone & - & - & +++ & - & + & ++ & +++ & $+/-$ \\
\hline AS & $\mathrm{F}$ & 46 & Neomicine & Antraquinone & - & - & +++ & - & $+/-$ & + & ++ & $+/-$ \\
\hline ER & $M$ & 49 & P-phenylenediamine & Antraquinone & - & - & +++ & - & $+/-$ & ++ & +++ & $+/-$ \\
\hline $\mathrm{IL}$ & $\mathrm{F}$ & 49 & Quarternium 15 & Antraquinone & - & - & +++ & - & $+/-$ & + & + & $+/-$ \\
\hline$A C$ & $\mathrm{~F}$ & 49 & Quinolina mix & Antraquinone & - & - & +++ & - & $+/-$ & ++ & +++ & $+/-$ \\
\hline LG & $\mathrm{F}$ & 46 & Balsamo Peru & Antraquinone & - & - & +++ & - & $+/-$ & + & +++ & $+/$ \\
\hline MG & $\mathrm{F}$ & 29 & Nickel & Antraquinone & - & - & +++ & - & $+/-$ & + & ++ & $+/-$ \\
\hline SA & $\mathrm{F}$ & 64 & Irgasan & Antraquinone & - & - & +++ & - & $+/-$ & + & ++ & $+/-$ \\
\hline TV & $\mathrm{F}$ & 23 & Nickel & Antraquinone & - & - & +++ & - & $+/-$ & + & +++ & $+/-$ \\
\hline
\end{tabular}

\footnotetext{
* Skin erythema, papule and vesicle: - (absent); + (mild); ++ (moderate); +++ (intense). ${ }^{* *}$ Mononuclear cell infiltration: +/- (scattered); + (mild); ++ (moderate); +++ (intense). See Material and Methods.
} 

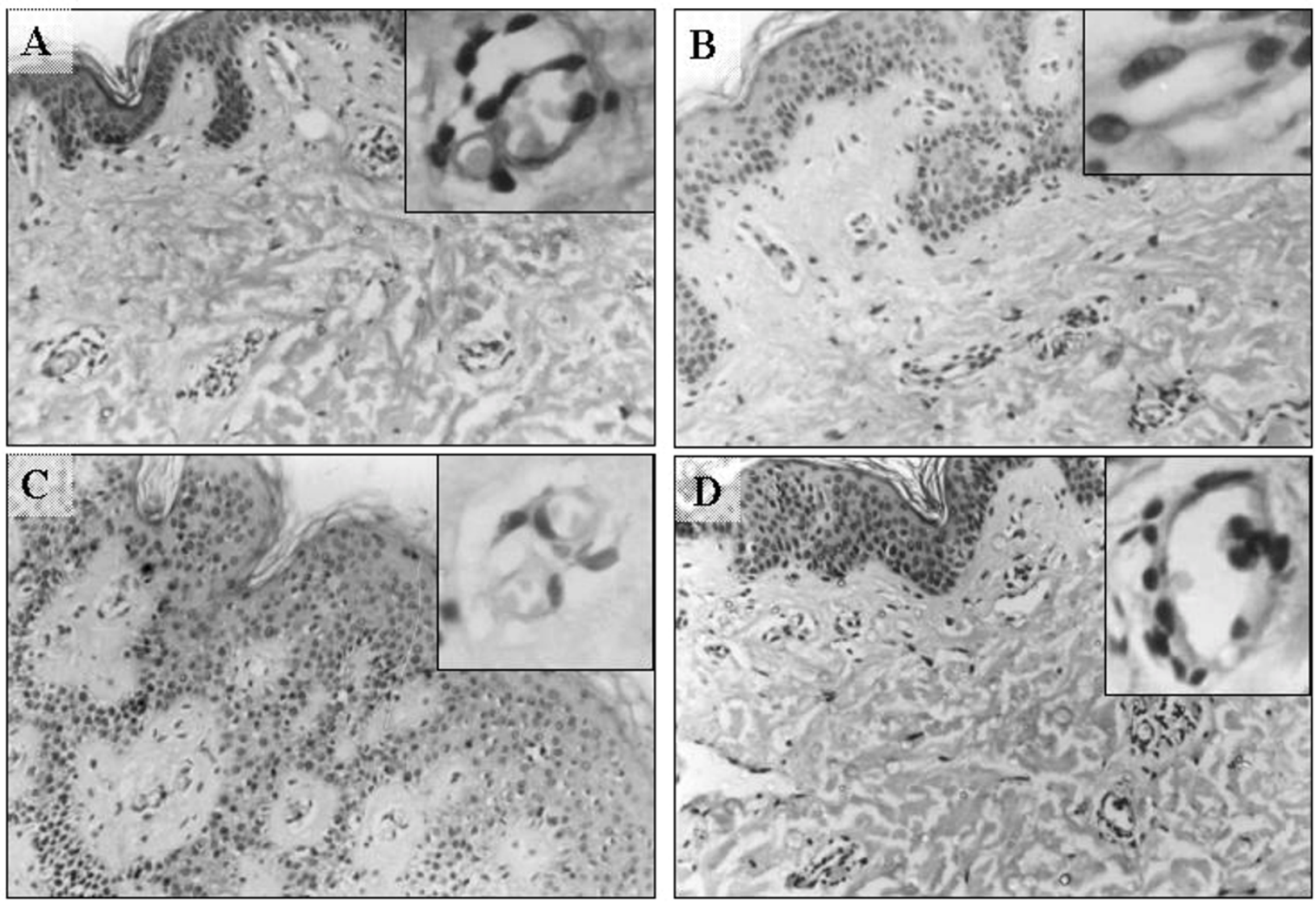

\section{Figure I}

Micrograph of skin biopsies after specific $\mathrm{Ag}$ challenge at $2 \mathrm{~h}(\mathrm{~A}), 10 \mathrm{~h}(\mathrm{~B})$ and $48 \mathrm{~h}(\mathrm{C})$ and negative $\mathrm{Ag}$ site at $48 \mathrm{~h}(\mathrm{D})$ stained with hematoxilin/eosin. Insert in upper right of each image show enlarged views of BECs from the same tissue section. Original magnifications $\times 10$ and $\times 40$

slides were counterstained with hematoxilin and the sections were counted in duplicate on 14-17 adjacent fields at $1000 \times$ magnification blinded to the patient's clinical status. The number of mononuclear cells expressing a particular antigen were informed per $\mathrm{mm}^{2}$, whereas the expression of CS-1 fibronectin and CCL17 on blood vessels was measured using the following criteria (negative, low = less than $40 \%$ of blood vessels, intermediate = between 40 and $70 \%$ of blood vessels, and high $=$ more than $70 \%$ of blood vessels).

\section{Statistical analysis}

Variability of the parameters studied was analyzed with Friedman's test, followed by two-by-two comparisons between time points using the Wilcoxon signed rank test. Correlation coefficients were obtained by Spearman's method with correction for tied values. For all tests, $\mathrm{p}<$ 0.05 was considered significant.

\section{Results}

All subjects exhibited a specific antigen-induced clinical cutaneous response and a moderate to intense infiltration of mononuclear cells distributed mainly around BECs at 48 hours. Although the macroscopic response to the positive antigens were negative at 10 hours, skin biopsies of these sites showed a mild infiltration of mononuclear cells. At 48 hours, the sham challenged sites showed cell infiltrate comparable to the positive antigen sites at 2 hours (Table 1).

The histopathologic study of BECs from positive patch tests at 48 hours showed a significant hypertrophy and swelling compared to negative patch tests. This changes started to appear at 2 hours where the vessels showed an incipient but significant swelling (Figure 1).

Immunohistochemistry studies in all patients demonstrated that CS-1 fibronectin expression started very early 

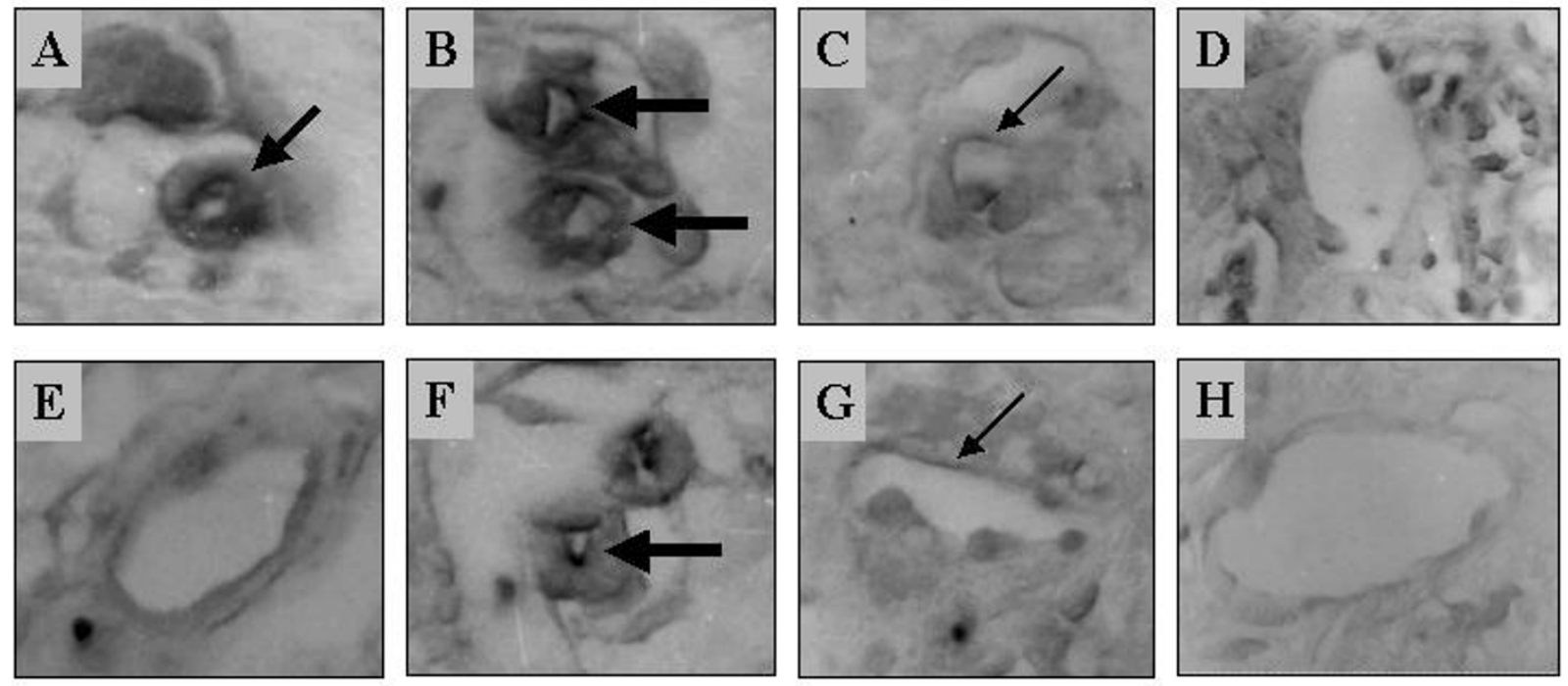

\section{Figure 2}

Micrograph of biopsies after specific $\mathrm{Ag}$ challenge at $2 \mathrm{~h}(\mathrm{~A}, \mathrm{E}), 10 \mathrm{~h}(\mathrm{~B}, \mathrm{~F})$ and $48 \mathrm{~h}(\mathrm{C}, \mathrm{G})$, and negative $\mathrm{Ag}$ site at $48 \mathrm{~h}(\mathrm{D}, \mathrm{H})$ stained for CS-fibronectin (A-D) and CCLI7 $(E-H)$. Original magnifications $\times 40$.

( 2 hours) in the lumen of endothelial cells in less than $40 \%$ of vessels and at 10 hours more than $70 \%$ of vessels from positive patch tests' samples were positive for this protein. By contrast, CCL17 expression was only seen after 10 hours in less than $40 \%$ of vessels and scattered keratinocytes throughout the epidermis. The number of blood vessels expressing both molecules decreased at 48 hours and no immunoreactivity was found in biopsies from the negative control challenge sites (Figure 2).

There were significant increases in $\alpha 4 \beta 1+(C D 49 d)$, CD3+ and CD68+ cells at positive antigen challenged sites at all time points compared with negative antigen challenged sites $(\mathrm{p}<0.0001)$. The numbers of $\alpha 4 \beta 1+, \mathrm{CD} 3+$ and CD68+ cells were maximal 48 hours after the specific antigen challenge. $\mathrm{T}$ lymphocytes were observed mainly around blood vessels whereas $\alpha 4 \beta 1+$ cells and CD68+ macrophages were distributed throughout the dermis and the numbers of these infiltrating cells at 48 and 10 hours were significantly higher than those at 10 and 2 hours, respectively $(\mathrm{p}<0.004)$ (Figure 3A).

As shown in figure 3B, significant differences (Ag- and 2-, 10- and 48-hours specific Ag challenge time points) were observed for CCR5 + cells $(\mathrm{p}<0.003)$, CXCR3+ cells $(\mathrm{p}<$ $0.003)$, and CCR $3+$ cells $(p<0.003)$. The numbers of CXCR3+ and CCR5+ infiltrating cells at the specific antigen challenge sites increased significantly between 2 and 10 hours $(\mathrm{p}<0.03)$. This was not seen with CCR3+ cells. Moreover, there was also significant differences between for CXCR3+, CCR5+, and CCR3+ cells at 48 versus 10 hours $(p<0.007)$. Mononuclear cells expressing any of the three CR keep raising until 48 hours and approximately $59 \%$ were CXCR3+, $42 \%$ were CCR5+ whereas only $14 \%$ were CCR $3+$. There was a significant correlation between the numbers of cells expressing CXCR3 and CCR5 protein at 10 and 48 hours ( $\mathrm{rs}=0.9 ; \mathrm{p}=0.0007)$.

\section{Discussion and Conclusions}

Efficient recruitment into inflamed skin requires exceptional adhesive interactions between mononuclear cells and the inflamed endothelial cell lining of draining blood vessels. In addition to the expression of E-selectin, CCL17, CXCL16, CX3CL1, and increased numbers of integrin ligands [33-35], we show here for the first time a very early production of CS-1 fibronectin by activated endothelial cells in patients with ACD. The expression of this molecule may contribute to the enhanced stickiness of monocytes and T cells expressing $\alpha 4 \beta 1$ integrin.

Within the extracellular matrix components fibronectin play an important role in lymphocyte trafficking by integrins-ligands interaction. Activated lymphocytes express $\alpha 4 \beta 1$ integrin which bind not only to VCAM- 1 but to specific sites on the fibronectin molecule, the connecting segment-1 (CS-1) motif present in alternatively spliced variants [31].

Enhanced adhesion of $\alpha 4 \beta 1+\mathrm{T}$ lymphocytes to CS- 1 fibronectin in vitro has been shown in patients with vascu- 

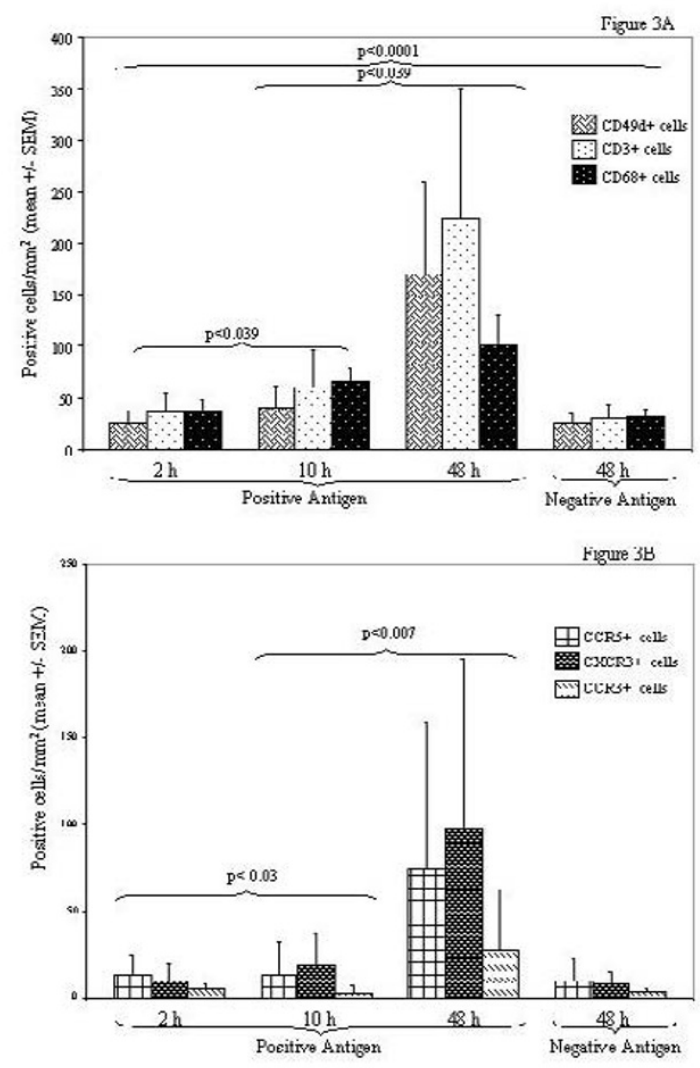

\section{Figure 3}

Numbers of positive cells (mean $+/$ - SEM) per square millimeter of $\alpha 4 \beta I+(C D 49 d), C D 3+$ and CD68+ (A), CCR5+, CXCR3+ and CCR4+ (B) infiltrating cells in antigen-challenged skin biopsies. Negative antigen-challenged sites ( $\mathrm{Ag}-)$ at $48 \mathrm{~h}$ were used as control. Significant differences (Ag- and 2-, 10- and 48-h specific Ag challenge time points; Friedman's test) were observed for CD3+ T lymphocytes $(p<0.000 \mathrm{I})$, CD68+ macrophages $(p<0.0001)$, CXCR3+ cells $(p<$ $0.003)$, CCR4+ cells $(p<0.003)$, and CCR3+ cells $(p<$ $0.003)$.

litis and rheumatoid arthritis and this molecule was selectively expressed in synovial endothelium from biopsies with rheumatoid arthritis but not in normal synovium $[32,36]$.

CS-1 fibronectin and CCL17 are probably most important in the rapid adhesion step, because of their presentation by endothelial cells. Indeed they trigger rapid adhesion to VCAM-1 and ICAM-1 of monocytes and T cells rolling on E-selectin. Thus CS-1 fibronectin may work together with CCL17 inducing adhesion of passing cutaneous $\alpha 4 \beta 1+/$ CCR4+ mononuclear cells under shear.
We also report here that CCL17 is also produced by scattered keratinocytes in patients with ACD which since to be similar to the finding of Vestergaard $\mathrm{C}$ et al in skin biopsies from patients with atopic dermatitis [29]. This chemokine may work together with CCL27 and MCP-1/CCL2 which are also produced by activated keratinocytes [30], and may subsequently attract the adherent cells into the epidermis of patients with ACD.

Since induction of CS-1 fibronectin production has also been reported by us in lesional skin from patients with atopic dermatitis and irritative contact dermatitis [Martín AP; Ortiz S; Cabalier MED; Frede S; Burgos E; Hliba E; Serra, HM. In press Journal Cutaneous Pathology], it is inferred that this early inflammatory molecule is expressed in skin's BEC upon different types of stimulus in a non antigen-specific manner.

So a useful therapeutic strategy in dermatitis may be to block $\alpha 4 \beta 1$ and CCR 4 interactions with its ligands on inflamed endothelial cell surfaces, by specific antibodies or antagonists. In this regard, CS- 1 analogue peptide have been efficiently used to diminish the efferent phases of Th 2 and Th1 mediated inflammatory responses in animal models [[37,38], Serra et al, in preparation].

T lymphocytes with polarized cytokine production (Th1 and Th2) show a different distribution of inflammatory CR, with CXCR3 and CCR5 transcripts markedly enhanced in Th1 cells and increased amounts of transcripts for CCR3, CCR4 and CCR8 in Th2 cells [39]. Moreover a large body of evidences indicate that the chemokine receptor CXCR3 and CCR5 are markers for T cells associated with certain inflammatory reactions, particularly TH-1 type reactions [40,41].

In our kinetic study over a 48 hours course of provoked human allergic contact dermatitis we found a gradual and higher accumulation of CXCR3 + than CCR5+ cells which was directly associated with CD3+ T cells. Flier J et al have demonstrated differences in chemokine expression between ACD and ICD reactions being CXCL9, CXCL10 and CXCL11 only detected in the allergic patch test lesions [42]. Interestingly the proportion of cells in our allergic patch test reactions expressing CCR 5 was lower than those that were CXCR3+, providing new evidences to the findings of Yamamoto et al. who has demonstrated that CXCR3 is the best marker for identification of circulating Th1 effector population because Th1-type cytokine-producing cells resided not only in CCR5-positive CD4+ T cells but also in those that were CCR5-negative [43].

IL-17 is an important player of CD4+ T cell-mediated skin inflammation in ACD with synergistic (ICAM-1, IL-8) or antagonist (RANTES) effects on IFN-gamma-stimulated 
keratinocyte activation [44]. Our results also confirmed the finding of Albanesi et al. who have shown that the majority of infiltrating cells in ACD are recruited by CXCR3 agonistic chemokines released by keratinocytes activated with IFN-gamma and TNF-alpha or IFN-gamma and IL-4 [45]. But here IL-4 exerts a proinflammatory function on keratinocytes by potentiating IFN-gamma and TNF-alpha induction of IP-10, Mig, and I-TAC, which in turn may determine a prominent recruitment of CXCR3+ $\mathrm{T}$ lymphocytes at inflammatory reaction sites.

Our findings of a small number of CCR3+ cells infiltrating the skin at 48 hours could be due to the present of T cells releasing high levels of IL-10, low IFN- $\gamma$, and undetectable IL-4 (Th IL-10) which have been reported to represent an important mechanism for terminating Th1-mediated allergic reactions and limiting excessive tissue damage. They have a broad array of functional T1- and T2-associated chemokine receptors, but also express high levels of CCR2 and CCR8 which allow resting as well as activated Th $\mathrm{IL}-10$ cells to display a significant migratory capacity to CCL2 and CCL1 [46].

\section{Competing interests}

None declared.

\section{Authors' contributions}

APM carried out the immunohistochemical studies, performed the statistical analysis and drafted the manuscript. GN performed the clinical evaluation of the patients. JG performed the skin patch tests and read the macroscopic responses. SO carried out some of the immunohistochemical and conventional histopathological studies. ARL carried out the clinical evaluation of the patients and took the biopsies. AD carried out the conventional histopathological studies. MCD performed the skin patch test and read the macroscopic responses. AK performed the skin patch test and read the macroscopic responses. ALM conceived of the study, and participated in its design and coordination. HMS conceived of the study, and participated in its design and coordination.

All authors read and approved the final manuscript.

\section{Acknowledgements}

We thank Dr. Hliba for excellent technical acquisition of images and María Angela Mandolini for her excellent technical assistance.

This work was partially supported by Agencia Córdoba Ciencia and SECYT (UNC).

\section{References}

I. Grabbe S, Schwarz T: Immunoregulatory mechanisms involved in elicitation of allergic contact hypersensitivity. Immunol Today 1998, 19:37-43

2. Enk AH: Allergic contact dermatitis: understanding the immune response and potential for targeted therapy using cytokines. Mol Med Today 1997, 3:423-428
3. Mortz CG, Andersen KE: Allergic contact dermatitis in children and adolescents. Contact Dermatitis 1999, 4I:121-130

4. Krasteva M, Kehren J, Sayag M, Ducluzeau MT, Dupuis M, Kanitakis J, Nicolas JF: Contact dermatitis II. Clinical aspects and diagnosis. Eur J Dermatol 1999, 9:144-159

5. Elston D, Licata A, Rudner E, Trotter K: Pitfalls in patch testing. Am J Contact Dermat 2000, I I:184- I88

6. Morhenn VB, Chang EY, Rheins LA: A noninvasive method for quantifying and distinguishing inflammatory skin reactions. $J$ Am Acad Dermatol 1999, 41:687-692

7. Kimber I, Dearman RJ, Cumberbatch M, Huby RJ: Langerhans cells and chemical allergy. Curr Opin Immunol 1998, I0:614-619

8. Patterson S: Flexibility and cooperation among dendritic cells. Nat Immunol 2000, I:273-274

9. Geijtenbeek TB, Krooshoop DJ, Bleijs DA, van Vliet S], van Duijnhoven GC, Grabovsky V, Alon R, Figdor CG, van Kooyk Y: DC-SIGNICAM-2 interaction mediates dendritic cell trafficking. Nat Immunol 2000, I:353-357

10. Aiba S, Manome $\mathrm{H}$, Yoshino $\mathrm{Y}$, Tagami $\mathrm{H}$ : In vitro treatment of human transforming growth factor-betal-treated monocytederived dendritic cells with haptens can induce the phenotypic and functional changes similar to epidermal Langerhans cells in the initiation phase of allergic contact sensitivity reaction. Immunology 2000, 10I:68-75

II. Van Den Broeke LT, Heffler LC, Tengvall Linder M, Nilsson JL, Karlberg AT, Scheynius A: Direct Ni2+ antigen formation on cultured human dendritic cells. Immunology 1999, 96:578-585

12. Vollmer J, Weltzien HU, Moulon C: TCR reactivity in human nickel allergy indicates contacts with complementarity-determining region 3 but excludes superantigen-like recognition. I Immunol 1999, 163:2723-273 I

13. Budinger L, Neuser N, Totzke U, Merk HF, Hertl M: Preferential usage of TCR-Vbeta 7 by peripheral and cutaneous T cells in nickel-induced contact dermatitis. J Immunol 200I, 167:60386044

14. Zhang L, Tinkle SS: Chemical activation of innate and specific immunity in contact dermatitis. J Invest Dermatol 2000, I I 5:168176

15. Dilulio NA, Engeman T, Armstrong D, Tannenbaum C, Hamilton TA, Fairchild RL: Groalpha-mediated recruitment of neutrophils is required for elicitation of contact hypersensitivity. Eur J Immunol 1999, 29:3485-3495

16. Ulrich P, Grenet O, Bluemel J, Vohr HW, Wiemann C, Grundler O, Suter W: Cytokine expression profiles during murine contact allergy: $\mathbf{T}$ helper 2 cytokines are expressed irrespective of the type of contact allergen. Arch Toxicol 200I, 75:470-479

17. Krasteva M, Kehren J, Ducluzeau MT, Sayag M, Cacciapuoti M, Akiba H, Descotes J, Nicolas JF: Contact dermatitis I. Pathophysiology of contact sensitivity. Eur J Dermatol 1999, 9:65-77

18. Traidl C, Sebastiani S, Albanesi C, Merk HF, Puddu P, Girolomoni G, Cavani A: Disparate cytotoxic activity of nickel-specific CD8+ and CD4+ T cell subsets against keratinocytes. J Immunol 2000 , 165:3058-3064

19. Askenase PW: Yes T cells, but three different T cells (alphabeta, gammadelta and NK T cells), and also B-I cells mediate contact sensitivity. Clin Exp Immunol 200 I, I 25:345-350

20. Borg L, Christensen JM, Kristiansen J, Nielsen NH, Menne T, Poulsen LK: Nickel-induced cytokine production from mononuclear cells in nickel-sensitive individuals and controls. Cytokine profiles in nickel-sensitive individuals with nickel allergy-related hand eczema before and after nickel challenge. Arch Dermatol Res 2000, 292:285-291

21. Probst P, Kuntzlin D, Fleischer B: TH2-type infiltrating $\mathbf{T}$ cells in nickel-induced contact dermatitis. Cell Immunol 1995, I65:134140

22. Dearman RJ, Kimber I: Cytokine fingerprinting: characterization of chemical allergens. Methods 1999, 19:56-63

23. Trautmann A, Akdis M, Kleemann D, Altznauer F, Simon HU, Graeve T, Noll M, Brocker EB, Blaser K, Akdis CA: T cell-mediated Fasinduced keratinocyte apoptosis plays a key pathogenetic role in eczematous dermatitis. J Clin Invest 2000, 106:25-35

24. Girolomoni G, Sebastiani S, Albanesi C, Cavani A: T-cell subpopulations in the development of atopic and contact allergy. Curr Opin Immunology 200I, 13:733-737

25. Trautmann A, Akdis M, Schmid-Grendelmeier P, Disch R, Brocker EB, Blaser K, Akdis CA: Targeting keratinocyte apoptosis in the 
treatment of atopic dermatitis and allergic contact dermatitis. J Allergy Clin Immunol 200I, 108:839-846

26. Campbell JJ, Haraldsen G, Pan J, Rottman J, Qin S, Ponath P, Andrew DP, Warnke R, Ruffing N, Kassam N, et al: The chemokine receptor CCR4 in vascular recognition by cutaneous but not intestinal memory T cells. Nature 1999, 400:776-780

27. Morales J, Homey B, Vicari AP, Hudak S, Oldham E, Hedrick J, Orozco R, Copeland NG, Jenkins NA, McEvoy LM, et al: CTACK, a skin-associated chemokine that preferentially attracts skin-homing memory T cells. Proc Natl Acad Sci USA 1999, 96: I 4470-I 4475

28. Ying S, Robinson DS, Meng Q, Barata LT, McEuen AR, Buckley MG, Walls AF, Askenase PW, Kay B: C-C Chemokines in Allergen-Induced Late-Phase Cutaneous Responses in Atopic Subjects: Association of Eotaxin with Early 6-Hour Eosinophils, and of Eotaxin-2 and Monocyte Chemoattractant Protein-4 with the Later 24-Hour Tissue Eosinophilia, and Relationship to Basophils and Other C-C Chemokines (Monocyte Chemoattractant Protein-3 and RANTES). I Immunol 1999, 163:39763984

29. Vestergaard C, Bang K, Gesser B, Yoneyama H, Matsushima K, Larsen CG: A Th2 chemokine, TARC, produced by keratinocytes may recruit CLA+CCR4+ lymphocytes into lesional atopic dermatitis skin. I Invest Dermatol 2000, I I 5:640-646

30. Goebeler M, Trautmann A, Voss A, Brocker EV, Toksoy A, Gillitzer $R$ : Differential and sequential expression of multiple chemokines during elicitation of allergic contact hypersensitivity. Am J Pathol 200I, I 58:431-440

31. Guan JL, Hynes RO: Lymphoid cells recognize an alternatively spliced segment of fibronectin via the integrin receptor alpha 4 beta I. Cell 1990, 60:53-6I

32. Elices MJ, Tsai V, Strahl D, Goel AS, Tollefson V, Arrhenius T, Wayner EA, Gaeta FC, Fikes JD, Firestein GS: Expression and functional significance of alternatively spliced CSI fibronectin in rheumatoid arthritis microvasculature. / Clin Invest 1994, 93:405-4I6

33. Butcher EC, Williams M, Youngman K, Rott L, Briskin M: Lymphocyte trafficking and regional immunity. Adv Immunol 1999, 72:209-253

34. Bazan JF, Bacon KB, Hardiman G, Wang W, Soo K, Rossi D, Greaves DR, Zlotnik A, Schall TJ: A new class of membrane-bound chemokine with a CX3C motif. Nature 1997, 385:640-644

35. Matloubian M, David A, Engel S, Ryan JE, Cyster JG: A transmembrane CXC chemokine is a ligand for HIV-coreceptor Bonzo. Nat Immunol 2000, I:298-304

36. Takeuchi T, Amano K, Sekine H, Koide J, Abe T: Upregulated expression and function of integrin adhesive receptors in systemic lupus erythematosus patients with vasculitis. J Clin Invest 1993, 92:3008-3016

37. Metzger WJ: Therapeutic approaches to asthma based on VLA-4 integrin and its counter receptors. Springer Semin Immunopathol 1995, 16:467-78

38. Yusuf-Makagiansar H, Anderson ME, Yakovleva TV, Murray JS, Siahaan T]: Inhibition of LFA-I/ICAM-I and VLA-4/VCAM-I as a therapeutic approach to inflammation and autoimmune diseases. Med Res Rev 2002, 22:146-167

39. Moser B, Loetscher P: Lymphocyte traffic control by chemokines. Nat Immunol 200I, 2:123-128

40. Qin S, Rottman JB, Myers P, Kassam N, Weinblatt M, Loetscher M, Koch AE, Moser $B$, Mackay CR: The chemokine receptors CXCR3 and CCR5 mark subsets of $T$ cells associated with certain inflammatory reactions. J Clin Invest 1998, I 0 I:746-754

4I. Abu El-Asrar AM, Struyf S, Al-Mosallam AA, Missotten L, Van Damme J. Geboes K: Expression of chemokine receptors in vernal keratoconjunctivitis. Br J Ophthalmol 200I, 85: I357-I36I

42. Flier J, Boorsma DM, Bruynzeel DP, Van Beek PJ, Stoof TJ, Scheper R, Willemze R, Tensen CP: The CXCR3 activating chemokines IP. 10, Mig, and IP-9 are expressed in allergic but not in irritant patch test reactions. J Invest Dermatol 1999, I I 3:574-578

43. Yamamoto J, Adachi $Y$, Onoue $Y$, Adachi YS, Okabe $Y$, Itazawa T, Toyoda M, Seki T, Morohashi M, Matsushima K, et al: Differentia expression of the chemokine receptors by the ThI- and Th2 type effector populations within circulating CD4+ T cells. J Leukocyte Biology 2000, 68:568-574

44. Albanesi C, Cavani A, Girolomoni G: IL-I 7 is produced by nickelspecific T lymphocytes and regulates ICAM-I expression and chemokine production in human keratinocytes: synergistic or antagonist effects with IFN-gamma and TNF-alpha. J Immunol 1999, 162:494-502

45. Albanesi C, Scarponi C, Sebastiani S, Cavani A, Federico M, De Pita O, Puddu P, Girolomoni G: IL-4 enhances keratinocyte expresión of CXCR3 agonistic chemokines. J Immunol 2000, 165:1395-1402

46. Sebastiani S, Allavena P, Albanesi C, Nasorri F, Bianchi G, Traidl C, Sozzani S, Girolomoni G, Cavani A: Chemokine receptor expression and function in CD4+ T lymphocytes with regulatory activity. J Immunol 200I, 166:996-1002

\section{Pre-publication history}

The pre-publication history for this paper can be accessed here:

http://www.biomedcentral.com/1471-5945/2/9/prepub
Publish with BioMed Central and every scientist can read your work free of charge

"BioMedcentral will be the most significant development for disseminating the results of biomedical research in our lifetime." Paul Nurse, Director-General, Imperial Cancer Research Fund

Publish with BMC and your research papers will be: - available free of charge to the entire biomedical community - peer reviewed and published immediately upon acceptance - cited in PubMed and archived on PubMed Central

- yours - you keep the copyright
BioMedcentral.com editorial@biomedcentral.com 